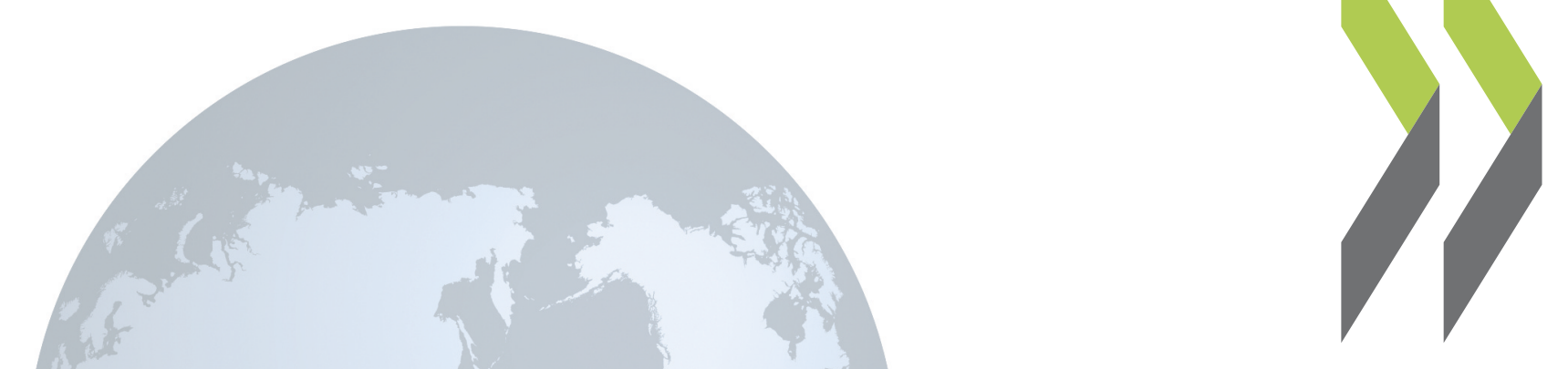

OECD Regional Development Working Papers 2019/03

Promoting Indigenous community economic development, entrepreneurship and SMEs in a rural context

Chris McDonald 


\title{
Promoting Indigenous community economic development, entrepreneurship and SMEs in a rural context
}

\author{
By: Chris McDonald
}

This paper establishes an analytical framework for understanding and assessing Indigenous economic development and well-being in a place-based context. It identifies the importance of flexibility in geographic scale for organising policies for Indigenous communities, development objectives that reflect the selfdetermined and informed choices of Indigenous peoples, and implementing strategies for development based on the identification of local assets.

Key words: Indigenous peoples, place, well-being, regional and rural development, sustainable development goals, culture:

JEL codes: R58 


\section{ABOUT THE OECD}

The OECD is a multi-disciplinary inter-governmental organisation of 36 member countries which engages in its work an increasing number of non-members from all regions of the world. The Organisation's core mission today is to help governments work together towards a stronger, cleaner, fairer global economy. Through its network of 250 specialised committees and working groups, the OECD provides a setting where governments compare policy experiences, seek answers to common problems, identify good practice, and coordinate domestic and international policies.

\section{ABOUT THE REGIONAL DEVELOPMENT WORKING PAPERS}

Working papers from the Regional Development Policy Division of the OECD cover a full range of topics including regional statistics and analysis, urban governance and economics, rural governance and economics, and multi-level governance. Depending on the programme of work, the papers can cover specific topics such as regional innovation and networks, the determinants of regional growth or fiscal consolidation at the sub-national level. OECD Regional Development Working Papers are published on http://www.oecd.org.cfe/regional-policy.

This paper is published under the responsibility of the Secretary-General of the OECD. The opinions expressed and the arguments employed herein do not necessarily reflect the official views of OECD member countries.

This paper was authorised for publication by Lamia Kamal-Chaoui, Director, Centre for Entrepreneurship, SMEs, Regions and Cities.

This document, as well as any [statistical] data and map included herein, are without prejudice to the status of or sovereignty over any territory, to the delimitation of international frontiers and boundaries and to the name of any territory, city or area.

C OECD 2019 You can copy, download or print OECD content for your own use, and you can include excerpts from OECD publications, databases and multimedia products in your own documents, presentations, blogs, websites and teaching materials, provided that suitable acknowledgment of OECD as source and copyright owner is given. All requests for commercial use and translation rights should be submitted to rights@ oecd.org 


\section{Acknowledgements}

This report was prepared by the Centre for Entrepreneurship, SMEs, Regions and Cities (CFE) led by Lamia Kamal-Chaoui, Director. It was produced as part of the programme of work of the OECD of the Regional Development Policy Committee (RDPC).

This report was made possible through the support and feedback of Professor David Freshwater (University of Kentucky), Jonathan Barr (OECD LEED Committee), and policy makers of OECD member countries (Australia, Canada, New Zealand, Sweden and the United States).

The report was authored by Chris McDonald under the supervision of José Enrique Garcilazo, Head of the Regional and Rural Policy Unit in the Regional Development and Tourism Division led by Alain Dupeyras.

Special thanks also goes to the Sami Parliament of Sweden who provided valuable comments as well. 


\section{Table of contents}

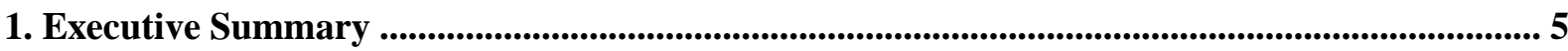

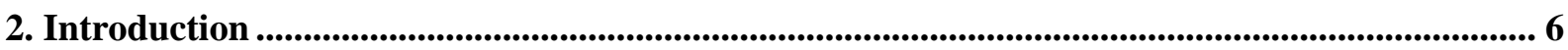

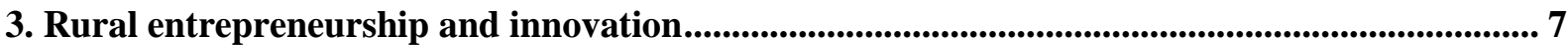

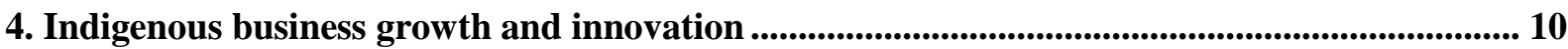

5. Rural development policies and strategies .................................................................................................... 14

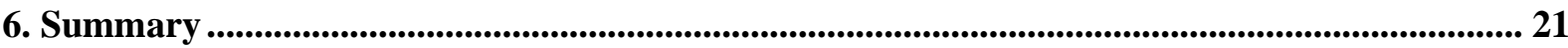

7. Bibliography

\section{Tables}

Table 3.1. Factors impacting on entrepreneurship and business performance in rural areas 8

Table 4.1. Factors impacting on business start-ups and growth in Indigenous communities in rural areas

Table 5.1. Rural Policy 3.0

\section{Boxes}

Box 5.1. Legal instruments to enable negotiation between Indigenous communities and mining proponents 


\section{Executive Summary}

- Indigenous businesses can take diverse forms including being initiated by individual entrepreneurs, linked to collective efforts to improve community wellbeing, and joint ventures with non-Indigenous entrepreneurs and organisations.

- There are a wide range of business activities undertaken by Indigenous peoples across different countries ranging from natural resource based activities that are integrated into global value chains to subsistence agriculture and traditional livelihoods that are not.

- Cultural values and norms influence the nature of Indigenous entrepreneurship, and economic development policies should be designed in a way that matches these values, and recognises the different levels and diversity of economic activity undertaken by Indigenous peoples.

- A key to sustained Indigenous economic development in rural areas is creating the conditions for the growth of businesses that are competitive in regional, national and international markets - over time the growth of these businesses can break dependency relationships and support self-determination.

- Businesses in rural areas face a number of challenges such as distance to markets, lower levels of skills, access to finance and specialised business development services, and the availability of business premises - these challenges tend to be amplified for Indigenous businesses in rural areas.

- Three key factors are identified as important to creating an enabling environment for the growth and sustainability of Indigenous businesses in a rural context:

1. A place-based vision and priorities for Indigenous economic development that can facilitate the coordination of public and private investment to enabling factors, strengthen rural-urban linkages, participation in global value-chains, and facilitate product differentiation;

2. Mechanisms to negotiate shared benefit agreements with investors; and,

3. Initiatives that increase access to finance and markets for Indigenous owned businesses (e.g. community development finance and procurement) to support growth and value-adding opportunities. 


\section{Introduction}

The objective of this paper is to identify the key challenges, opportunities and policies to promoting Indigenous business growth and innovation in rural areas. The paper is divided into two parts. The first part provides a literature review about rural entrepreneurship and innovation. It begins by discussing the growth dynamics of low density economies and challenges and opportunities facing entrepreneurs in rural areas. This sets the context for a specific discussion about the nature of Indigenous entrepreneurship and innovation. It identifies three factors that are important to shaping entrepreneurship and innovation outcomes for Indigenous communities: institutions that enable the community to set objectives and implement a vision for development, mechanisms to negotiate benefit sharing agreements, and initiatives that improve finance and markets. The second part of the paper reviews the literature regarding the appropriate policy responses to these issues. It finds some commonalities between indigenous and non-indigenous rural development strategies; however, there are also important differences such as adapting governance, programs and legal instruments to forms of social organisation based on kinship, and incorporating traditional forms of knowledge and Indigenous values into decision-making and commercial ventures. 


\section{Rural entrepreneurship and innovation}

\subsection{Growth in low density economies}

Low density or rural economies have a development logic that is different to urban areas and this poses unique challenges and opportunities. Rural regions are diverse and highly influenced by their specific natural environments. They face challenges such as high reliance on extraction and first stage processing of local natural resource, long supply chains and sensitivity to transport costs, small and ageing workforce, weak local competition, and sensitivity to regional, national and global business cycles (OECD 2016). Growth can be driven by mobilising endogenous assets and is also strongly influenced by exogenous factors (OECD 2016). Research by the OECD emphasises the importance of proximity to cities and the tradeable sector as a driver of productivity and growth for rural economies. The tradeable sector includes goods and services that are mainly produced for sale to other than local buyers (OECD 2016). In order for the people in a rural community to remain employed, local firms must be competitive in either local or export markets. That is, they must be able to match the prices and quality of competing firms. The growth of the tradeable sector enables rural economies to grow beyond their home market, attract new investment and absorb technologies, and generate a multiplier effect as income flows into the region.

Rural areas close to cities generally have greater capacity to diversify in the tradeable sector, for example, leveraging linkages with cities through manufacturing activity and demand for rural amenities from urban residents. The tradeable sector in remote rural areas is usually narrow range of goods and services linked to natural resources and assets, for example, in areas such as agriculture, aquaculture and fisheries, forestry, mining, ecotourism, and/or renewable energy. Participation in global value chains (GVCs) can evolve in different ways in remote areas depending on access to markets, the level of development, factor endowments, and variations in the institutions (OECD 2018a). In most cases remote rural areas participate at the lower end of value chains - extraction, harvesting and first stage processing - in natural resource based industries that are exported far from the region. To increase productivity these industries have invested in labour saving technology, and remote areas have to confront the challenge of declining employment opportunities in areas such as agriculture, forestry and mining. For some remote areas, this has contributed to a cycle of economic and demographic decline as young people leave in search of job opportunities elsewhere.

There are many cases of remote rural areas that have moved up the value-chain to develop globally competitive value-adding manufacturing and services in areas such as forestry, mining, aquaculture, and agriculture (OECD 2016, 2016a). For example, equipment and machinery related to forestry in eastern Finland, aquaculture in northern Norway, and mining services and technological innovations in Australia. This is important for rural areas because it generates higher wage jobs, and increases the diversity and resilience of rural economies. There is no silver bullet to explain why some rural areas are to achieve this outcome and others do not. Access to natural resources and cities are important. Institutional factors - local leadership, understanding of assets and growth bottlenecks, a vision for development, and governance arrangements to deliver on this vision in an integrated way - are also important (OECD 2012). This paper focuses on how to drive growth through rural development strategies that foster entrepreneurship and facilitate 
innovation to promote value-adding and diversification in the tradeable sector for Indigenous communities in rural areas.

\subsection{Entrepreneurship and innovation in rural areas}

Enterprises are organisations that produce goods and services, which have some autonomy in decisions about the allocation of resources. Entrepreneurship describes an attempt to start a new enterprise or expand an existing business that creates social and economic value by a team or group of individuals (OECD 2009, 2017). These businesses generally exist to maximise profit. However, entrepreneurial strategies and forms of organisation can also be applied to meet social needs and deliver benefits for the common of a community (Noya and Clarence 2013, OECD 2017). Businesses in rural areas tend to be smaller than in urban areas with a higher proportion of micro SMEs (employment less than 10) (OECD 2015). The vast majority of rural SMEs have slow employment growth and remain microenterprises. Compared to urban areas, rural economies also have a higher proportion of firms in the traded sector (OECD 2016). The business structure in rural areas can also be different due to the existing large firms engaged in natural resource based activities (mining, forestry, agriculture and fisheries, and food processing). These firms undertake extraction and first stage processing and in some cases, local SMEs provide services to these larger businesses.

Innovation - the introduction of new processes and products - is increasingly important to the competitiveness of enterprises in national and international markets. In a few instances, there are formal science based innovation systems within rural remote regions. There are some examples of formal science based innovation in rural areas such as forestry and bioenergy research, and agricultural research. Imported innovations are important for rural areas. This is innovation that takes place elsewhere, but is adopted either by subsidiaries of multi-national firms bringing in new products or processes that their parent has developed or acquired, or by local firms licensing or emulating ideas developed elsewhere (OECD 2016a). Process innovations are significant but sometimes less obvious since it largely takes place within SMEs and may not be patented or even made known within the region since it can be specific to a single firm. These user driven innovations take place largely because the entrepreneur cannot find a viable solution to purchase and has to develop an internal way to resolve the problem. Rural business structures and innovation performance reflects a number of factors and challenges that are peculiar to rural economies (Table 3.1).

Table 3.1. Factors impacting on entrepreneurship and business performance in rural areas

\begin{tabular}{ll}
\hline $\begin{array}{l}\text { Factors impacting } \\
\text { business growth }\end{array}$ & Challenges for businesses in rural areas \\
\cline { 2 - 2 } $\begin{array}{l}\text { Longer distance to } \\
\text { markets }\end{array}$ & $\begin{array}{l}\text { Higher transportation and communication costs for businesses because the population is widely } \\
\text { scattered and distances to large national markets may be considerable. Provision of } \\
\text { telecommunications infrastructure can be poor because of the relatively low and dispersed nature of } \\
\text { the demand. }\end{array}$ \\
$\begin{array}{l}\text { Small size of local } \\
\text { markets }\end{array}$ & $\begin{array}{l}\text { Markets are smaller and more dispersed which reduces opportunities for knowledge spillovers, } \\
\text { sharing of inputs and competition, and specialisation. }\end{array}$ \\
$\begin{array}{l}\text { Access to research } \\
\text { and development }\end{array}$ & $\begin{array}{l}\text { There are few instances of large formal science based innovation systems within rural remote } \\
\text { areas, which are typically in larger cities with universities and firms large enough to support a formal }\end{array}$ \\
\hline R\&D function.
\end{tabular}




\begin{tabular}{ll}
\hline Lower levels of skills & $\begin{array}{l}\text { Historically many rural occupations did not require formal training, which has left a legacy of low levels } \\
\text { of human capital. In areas where business and population densities are low, access to training can } \\
\text { be more costly. }\end{array}$ \\
$\begin{array}{l}\text { Access to specialised } \\
\text { services }\end{array}$ & $\begin{array}{l}\text { Greater average distance from business advice and support services provided through the market } \\
\text { (such as from banks, accountants and consultants), and/or business development services provided } \\
\text { by the State or other institutions (e.g. business incubators) compared with urban-based enterprises. } \\
\text { Limited time and resources can also constrain demand for these services. }\end{array}$ \\
$\begin{array}{l}\text { Access to finance } \\
\text { Availability of } \\
\text { business premises }\end{array}$ & $\begin{array}{l}\text { Rural businesses can lack sufficient access to finance because enterprises are more likely to have } \\
\text { lower returns and banks and financial services may not be accessible. }\end{array}$ \\
$\begin{array}{l}\text { in localities where low levels of entrepreneurial activity depress the level of demand for business } \\
\text { property. }\end{array}$ \\
$\begin{array}{l}\text { Social and cultural } \\
\text { factors }\end{array}$ & $\begin{array}{l}\text { Socio-cultural values and preferences can affect small business development, through its influence } \\
\text { on gender roles, co-operation, communications and network composition. Attitudes about } \\
\text { expansion and the value of external assistance can also be an issue }\end{array}$ \\
\hline
\end{tabular}

Source: adapted from $\operatorname{OECD}(2009,2016)$

There are a number of policies and business strategies that can be utilised to overcome these locational disadvantages. Investment in transport and communications infrastructure helps reduce business costs and open up new market opportunities and ways to deliver public services. The public sector can step in to provide access to finance (such as through Community Development Finance Institutions), and the provision of appropriate premises for business start-ups. Business support services can be expanded and redesigned to reduce barriers to entry for small rural enterprises seeking to innovate, grow and access external markets. Large businesses in sectors such as forestry and mining can use vertical integration to overcome the need for sharing facilities. Firms in rural areas can also attract skilled workers through higher wages or by offering attractive quality of life packages through the availability of environmental amenities and lower housing costs. Another way that startups and SMEs adapt to low density peripheral areas is by specialising in niche markets (OECD 2009, 2016). 


\section{Indigenous business growth and innovation}

In addition to the traditional arguments regarding public policy support for entrepreneurs and SMEs (market failures such as asymmetric information and the inefficient allocation of credit), there are a number of important arguments to support Indigenous entrepreneurship and innovation. The first is that business growth can support selfdetermination because it can reduce dependency relationships and increase decisionmaking autonomy (Cornell 2006). Processes of colonisation and policies of assimilation have resulted in a lack of entrepreneurial activity and higher rates of individual dependency (in the form of welfare), and collective forms of dependency (in the form of government programs and subsidies) for Indigenous peoples in some countries (Cornell 2006, Lituchy et al. 2006). Indigenous businesses can help overcome dependency by providing local employment opportunities for residents and generating own-revenue for public goods including the provision of services on traditional lands (Native Nations Institute 2016, Cornell 2006, NSW Wales Ombudsman 2016). The second is that Indigenous entrepreneurs and business leaders also provide important role models for other Indigenous people (NSW Wales Ombudsman 2016). The third is that it can retain economic activity on traditional lands and promote regional economic development. Indigenous businesses also reduce income leakage from local communities and travel costs for residents, and if they can penetrate external markets also generate multiplier effects (Native Nations Institute 2016).

Some of the challenges faced by Indigenous communities reflect issues faced by any remote rural economy; however, they can be amplified in the case of traditional lands. During colonisation in settler societies such as Canada, Australia and the United States Indigenous people were stripped of assets and often moved into areas with limited commercial value (Altman 2004). If the ties between land and language and kinship groups were maintained it was often on land that was perceived to have little commercial worth in terms of agricultural production, and therefore with limited infrastructure and access to markets (Altman 2004, Native Nations Institute 2016). This can include lack of basic public infrastructure such as water and sanitation, roads and public transport services, schools and health clinics (International Council of Mining and Metals 2015). As a result, Indigenous communities can face complex social issues such as poor health, low educational attainment, and lack of digital capability (KPMG 2016). This lack of capability and competiveness can contribute to lower levels economic activity on Indigenous lands compared to surrounding regions. For example, Todd (2017) in a study of tribal communities in the United States found similar sectoral distributions in business establishments with surrounding regions but significantly small numbers of employer establishments per capita, particularly for reservations with fewer than 15,000 residents.

\subsection{Indigenous entrepreneurship in rural areas}

There are also a number of current and potential opportunities for Indigenous entrepreneurs and businesses in rural areas. Customary activities and traditional knowledge are an absolute advantage because it is embedded within a particular location and embodied within close kinship networks (e.g. as demonstrated by Indigenous arts, handicrafts, and music). However, it is important to note that indigenous people living in traditional settlement areas practicing customary activities also live in these places for non-market reasons, and have livelihoods that are not well integrated into market economies (Altman 
2004). Indigenous people living in traditional settlements also need to balance social and cultural obligations with employment and business operations (Taylor 2008). Indigenous populations in some countries (e.g. Australia and Canada) can also be younger and potentially have greater familiarity with digital technologies and more flexible and willing to take employment and entrepreneurial risks (KPMG 2016, New South Wales Ombudsman 2016). Opportunities for development will vary across different communities and can relate to developing markets for customary activities such as harvesting food, arts, handicrafts, and music, eco-tourism, medicinal and health products, and environmental services (e.g. natural resource management and carbon sequestration) (Altman 2004, Coria and Calfucura 2012, Cleary 2012, New South Wales Ombudsman 2016). There may also be potential for Indigenous entrepreneurs to take advantage of the disruption which is and will occur in agriculture and food production, mining, energy, and land and water management due to the Next Production Revolution (3D printing, Internet of Things, data driven production, and artificial intelligence), and continued global efforts to reduce carbon emissions (KPMG 2016).

There are different interpretations in the literature about the definition of indigenous entrepreneurship (Cornell 2006, Peredo and Anderson 2006). The first is that is simply entrepreneurship undertaken by Indigenous people. The second is that entrepreneurship is embedded in a particular territorial and institutional context, and social forms of organisation based around kinship embedded in particular places have an important influence in shaping Indigenous businesses and economies. From this second perspective Indigenous entrepreneurship can be defined as a new venture in a specific territory that is linked to a collective form of self-determination (Pareto and Anderson 2006). This includes sustaining indigenous language and culture, improving socio-economic conditions on traditional lands, and forms of enterprise that are closely related to community representative and political structures (Taylor 2008). Another characteristic of Indigenous businesses is partnership with non-Indigenous entities including businesses and nongovernment organisations to increase access to markets and capital, and technical expertise. However, it is important to recognise that some Indigenous communities can miss out on local benefits due to differences in bargaining power between indigenous communities, investors and corporations (Coria and Calfucura 2012). When combining these two definitions, Indigenous entrepreneurship can be defined as the creation, management development of new business ventures by Indigenous people, which is often connected with natural resources and notions of community-based economic development (Paredo and Anderson 2006).

\subsection{Indigenous business innovation}

In some OECD countries such as Canada, New Zealand, Australia and the United States, Indigenous peoples have developed nationally and internationally competitive businesses in areas such as gaming and tourism, mining, and food production. These businesses are based on individual and collective forms of entrepreneurship, and may participate in formalised innovation systems and clusters. For example, in Australia there are Indigenousowned mining services firms, and pastoral companies that compete in national and international markets. In New Zealand, Maori communities have been able to leverage land assets to establish successful agricultural and food processing companies which again compete in international markets. In order to compete effectively in the tradeable sector these companies (like any other business) develop process and product innovations, and absorb technologies to increase productivity. 
The scope and nature of innovation by Indigenous owned businesses is also influenced by social forms of organisation based on kinship and shared cultural values (Ronning 2007, Dana and Anderson 2007). For example, new business ventures are shaped by their cultural context in terms of supporting the reproduction of indigenous language and cultural practices. In rural areas, particularly in remote areas and traditional lands, innovation is likely to be shaped by the community's relationship to land (Drahos and Frankel 2012). This relationship is generally based on the principle that people are custodians of the land and connected to it for utilitarian (subsistence and trade), and spirituality reasons, and these rights are handed down in perpetuity through stories, arts and handicrafts, symbols and cultural practices. This traditional knowledge might relate to the cultivation and gathering of food, medicine and building materials, cultural symbols and handicrafts, and the management of land and water resources (Cleary 2012, Drahos and Frankel 2012). The development and use of these technologies is bounded within close kinship networks. They have also have evolved over hundreds and thousands of years as knowledge is accumulated about the natural environment, and ways to manipulate and exploit it have been refined to support subsistence and trade amongst Indigenous societies.

Indigenous forms of technological innovation challenge our traditional rule frameworks and programmes that are designed to incentivise and support innovation. Many of these technologies are based on tacit knowledge that has been handed down orally across generations. Because they are not the result of scientific discovery, or have not been scientifically tested, they may not be valued or recognised as legitimate in areas such as health, cosmetics, or natural resource management. As such, traditional Indigenous technologies are also not the property of the individual inventor. As a result, other actors (entrepreneurs and corporations) can appropriate Indigenous technologies. Indigenous Intellectual Property (IP) rights have been increasing source of controversy, discussion and policy responses in recent years. This includes the need to develop legal instruments regarding the use and protection of traditional knowledge, traditional cultural expressions, and biological material (Cleary 2012, Taubman 2012). Better addressing Indigenous IP issues relates to international and national legal frameworks related to trade, copyright, trademarks, and IP. Nation states and non-government organisations can also institute programmes related to the certification of Indigenous products and services to better protect Indigenous entrepreneurs.

\subsection{Enabling environment for Indigenous business growth at a regional level}

The first factor to create an enabling environment for Indigenous businesses are appropriate legal and regulatory mechanisms including those which give clarity about resource ownership and use rights, regulatory and administrative burdens regarding the use of land, and those which enable transparent agreements with outside commercial entities. The second are mismatches between Indigenous social and decision-making institutions and those which are needed to engage in commercial activities and distribute proceeds fairly amongst community members. This can include the capacity to resolve collective action problems within communities, and technical and financial capacities needed for commercial operations. The third is regarding access to capital and markets, which can include lack of information about markets to start and grow a business, which can be lacking due to factors such as discrimination and the inability to use land as collateral (Native Nations Institute 2016). A summary of these factors and evidence about them is outlined in Table 4.1. 
Table 4.1. Factors impacting on business start-ups and growth in Indigenous communities in rural areas

\begin{tabular}{|c|c|c|}
\hline Factors & Examples and evidence & Sources \\
\hline $\begin{array}{l}\text { Legal and regulatory } \\
\text { environment }\end{array}$ & $\begin{array}{l}\text { - Regulatory uncertainty and time-consuming and costly application } \\
\text { processes related to the commercial exploitation of fisheries, wildlife } \\
\text { and flora on Aboriginal land in Australia and Canada } \\
\text { - Lack of IP rights regarding traditional knowledge, traditional cultural } \\
\text { expressions, and biological material } \\
\text { - Lack of clarity regarding property rights related to sub-soil assets and } \\
\text { concessions to exploit them. } \\
\text { - Transparent legal mechanisms to enable joint commercial ventures and } \\
\text { benefit sharing agreements }\end{array}$ & $\begin{array}{l}\text { Altman (2004), } \\
\text { Disney (2010), } \\
\text { Williams (2010), } \\
\text { Cleary (2012) }\end{array}$ \\
\hline $\begin{array}{l}\text { Institutions and } \\
\text { decision-making }\end{array}$ & $\begin{array}{l}\text { - Indigenous social institutions of kinship and descent that are well } \\
\text { adapted to the customary practices, but poorly adapted to commercial } \\
\text { engagement. } \\
\text { - Poor perceptions about local political and bureaucratic decision-making } \\
\text { processes (e.g. lack of independence in dispute resolution processes, } \\
\text { political interference in business decision-making) } \\
\text { - Variability in resources and technical expertise in economic } \\
\text { development available to communities impacts on the efficacy of benefit } \\
\text { sharing agreements }\end{array}$ & $\begin{array}{l}\text { Altman (2004), } \\
\text { Williams (2010), Coria } \\
\text { and Calfucura (2011), } \\
\text { Native Nations } \\
\text { Institute (2016), Todd } \\
\text { (2017) }\end{array}$ \\
\hline $\begin{array}{l}\text { Access to capital and } \\
\text { markets }\end{array}$ & $\begin{array}{l}\text { - Non-standard land and property rights impact upon business } \\
\text { investment, low levels of capital and poor credit history } \\
\text { - Lack of technical expertise in terms of business regulation, and } \\
\text { developing business/financial plans } \\
\text { - Lack of information for potential investors, and about external market } \\
\text { opportunities } \\
\text { - Lack of financial institutions on or near traditional settlement areas, } \\
\text { discrimination and lack of knowledge about tribal lands and economies } \\
\text { - Limited access to private and public procurement } \\
\text { - Poor connectivity - transport and communications infrastructure and } \\
\text { services }\end{array}$ & $\begin{array}{l}\text { Coria and Calfucura } \\
\text { (2011), Native } \\
\text { Nations Institute } \\
\text { (2016), Todd (2017), } \\
\text { Williams (2010) }\end{array}$ \\
\hline
\end{tabular}




\section{Rural development policies and strategies}

Indigenous entrepreneurs in low-density economies face a number of challenges, which are typical to rural areas with the added complexity of legal arrangements, social institutions, capacity issues and levels of development, which are peculiar to Indigenous populations. Addressing these challenges will require tailored policy responses. This section of the paper reviews the literature regarding the appropriate policy responses to these issues. It begins by reviewing the OECD approach to rural development, entrepreneurship and innovation. There are some commonalities between indigenous and non-indigenous rural development strategies; however, there are also important differences such as adapting governance, programs and legal instruments to forms of social organisation based on kinship, and incorporating traditional forms of knowledge and Indigenous values into decision-making and commercial ventures.

\subsection{OECD rural development policies: entrepreneurship and innovation}

In terms of entrepreneurship and innovation, a key focus for rural development policies is how to overcome the challenge of distance and low densities, grow external markets, and diversify locally produced goods and services. This can be achieved through "bottom-up" economic development strategies that focus on regional competitive advantages and open up opportunities for related diversification and participation in global value chains (GVCs) (OECD 2016). There is no single policy recipe for achieving this outcome but policies tend to share the following characteristics: identification of absolute advantages supported by an evidence-base, working with entrepreneurs to identify bottlenecks/market failures associated with them, an emphasis on building networks, and investing in platforms to promote technology transfer. Rural development policies also require an integrated approach to investment across levels of government, and a focus on empowering rural communities to participate in decision-making through community capacity building (OECD 2016). Rural areas also benefit from strengthening linkages with metropolitan areas across different dimensions, for example, such as demographic (population movements, human capital, commuting), economic (e.g. local supply-chain linkages), the delivery of public services, and exchanges in amenities and environmental goods (OECD 2013a). These elements are captured by the OECD Rural Policy 3.0 (Table 5.1). 
Table 5.1. Rural Policy 3.0

\begin{tabular}{|c|c|c|c|}
\hline & Old paradigm & New rural paradigm & Rural Policy 3.0 \\
\hline Objectives & Equalisation & Competiveness & $\begin{array}{l}\text { Well-being considering multiple } \\
\text { dimensions of: i) the economy, ii) society } \\
\text { and iii) the environment }\end{array}$ \\
\hline Policy Focus & $\begin{array}{l}\text { Support for a single } \\
\text { dominant resource } \\
\text { sector }\end{array}$ & $\begin{array}{l}\text { Support for multiple } \\
\text { sectors based on their } \\
\text { competitiveness }\end{array}$ & $\begin{array}{l}\text { Low-density economies differentiated by } \\
\text { type of rural area }\end{array}$ \\
\hline Tools & Subsidies for firms & $\begin{array}{l}\text { Investments in qualified } \\
\text { firms and communities }\end{array}$ & $\begin{array}{l}\text { Integrated rural development } \\
\text { approach - spectrum of support to public } \\
\text { sector, firms and third sector }\end{array}$ \\
\hline $\begin{array}{l}\text { Key actors and } \\
\text { stakeholders }\end{array}$ & $\begin{array}{l}\text { Farm organisations and } \\
\text { national governments }\end{array}$ & $\begin{array}{l}\text { All levels of government } \\
\text { and all relevant } \\
\text { departments plus local } \\
\text { stakeholders }\end{array}$ & $\begin{array}{l}\text { Involvement of: i) public sector - multi-level } \\
\text { governance, ii) private sector - for-profit } \\
\text { firms and social enterprise, and iii) third } \\
\text { sector - non-governmental organisations } \\
\text { and civil society }\end{array}$ \\
\hline Policy approach & $\begin{array}{l}\text { Uniformly applied top } \\
\text { down policy }\end{array}$ & $\begin{array}{l}\text { Bottom-up policy, local } \\
\text { strategies }\end{array}$ & $\begin{array}{l}\text { Integrated approach with multiple policy } \\
\text { domains }\end{array}$ \\
\hline Rural definition & Not urban & $\begin{array}{l}\text { Rural as a variety of } \\
\text { distinct types of place }\end{array}$ & $\begin{array}{l}\text { Three types of rural: i) within a functional } \\
\text { urban area, ii) close to a functional urban } \\
\text { area, and iii) far from a functional urban } \\
\text { area }\end{array}$ \\
\hline
\end{tabular}

Source: OECD (2016)

\subsubsection{Promoting rural entrepreneurship}

There are a number of different programmatic interventions that are identified in the literature to support rural entrepreneurship (OECD 2009, 2016a). The first is providing support networks to help entrepreneurs capture the resources they need, which often includes some form of incubator programme (Henderson 2002). These can provide a platform to deliver a range of services to micro businesses such as legal and accounting services, and the provision of physical space to meet and work. They can also help address information asymmetries, for example by delivering programmes and activities that increase understanding about opportunities in external markets, particularly at the early stage of the business (Wyer and Smallbone 1999). The second relates to policies that promote an entrepreneurial culture in a local community (Henderson 2002, North and Smallbone 2006). This includes specialised training in entrepreneurship, promoting entrepreneurship as a career option to young people, mentoring, enterprise awards and promotion in local media (OECD 2009). OECD countries also usually have programmes targeted at SMEs to facilitate modernisation and upgrading through some combination of financial assistance, advice and consultancy, training and infrastructural improvements (OECD 2009). It is important these programmes are delivered in a way that matches the rural business environment, for example, outreach services to small remote communities, and lowering barriers to programme participation.

Specific population groups also face additional barriers to starting a business (such as women, youth, the unemployed, migrants and people with a disability) and this lens is important for designing Indigenous entrepreneurship strategies (OECD 2017). Entrepreneurship policies targeted to specific population groups seeks to raise awareness about entrepreneurship, and address specific market, institutional and behavioural failures that result in lower levels of business start-ups and ownership. Indigenous peoples have specific barriers related to resources that are necessary to start a business such as lack of collateral for loans, different forms of discrimination, and lack of social and cultural capital. Targeted programmes have been established in OECD countries related to entrepreneurship 
training, coaching and mentoring and finance which are designed to better address the needs of different population groups (OECD 2017). To ensure effectiveness this principle should also apply to Indigenous peoples and entrepreneurship.

\subsubsection{Regional and rural innovation strategies}

There are a number of key design principles which have been developed by the OECD for regional innovation strategies (OECD 2011). The first is the importance of an agreed vision and strategic framework to encourage innovation, which is based on regional assets and integrates relevant sectoral policies. The second is open and networked governance structures that engage a broad range of non-government actors (including SMEs, academics, and higher education and training institutions) with leaders that can demonstrate long-term political commitment to the vision and priorities. The third is structures which facilitate ongoing dialogue and feedback which is supported by clear metrics, evaluation, and scope for experimentation. Innovation strategies in rural remote areas should focus on core sectors where there is an existing absolute advantage and in improving connectivity to external markets. In terms of policy instruments it is important that programmes do not discriminate against innovators in rural areas. Forms of discrimination can include: a focus only on formal innovation systems where science based research and development activity is a prerequisite for support, focusing support only on innovations that have the potential for rapid growth (gazelles), requiring that an innovation be novel in a national or international context before it can be supported, establishing high minimum funding levels and complex application procedures that can be difficult for individuals or small firms to deal with, and concentrating efforts to promote innovation in urban areas (OECD 2016a).

\subsection{Indigenous entrepreneurship and innovation}

Strategies to promote entrepreneurship and innovation in traditional settlement areas are likely to share some characteristics with non-indigenous rural areas. These strategies will vary across different national territories given the starting point is self-determination and community-led economic development, and these places have different levels of development, institutional arrangements, histories and resource endowments. Given these local economies are small will be a need to prioritise areas of absolute and competitive advantage and develop the tradeable sector by strengthening links with external markets (including surrounding areas off-reserve). Governance arrangements and programmes to support entrepreneurship and innovation (with low barriers to entry) will also be needed to help address information asymmetries, access to capital and markets, and technical expertise.

However, there will also be some important differences with non-indigenous strategies to promote entrepreneurship and innovation. The level of development and existing engagement with markets is an important consideration. At a low level of engagement economic development might be more of a process to build capability to participate in local and regional economies (Altman 2004). This might include a focus on skills development, intermediate labour market programmes, and social enterprises linked to public procurement. Another consideration is how governance arrangements and programmes are adapted to social forms of organisation based around kinship relations. For example, how policy and legal instruments recognise the importance of commercial ventures that support indigenous languages and cultural practices, improve socio-economic conditions on traditional lands, and appropriately structure relationships with community representative and political structures (NSW Ombudsman 2016). Traditional knowledge is also a unique 
feature of Indigenous economies. It is important this knowledge is respected and there is informed consent regarding its use for commercial purposes (e.g. cultivation and gathering of food, medicine and building materials, cultural symbols and handicrafts, and the management of land and water resources).

\subsubsection{A collective vision for rural development is important}

A key success factor for self-determined and community-led economic development is the development of a collective vision and priorities for development (Native Nations Institute 2016). This is dependent on the formation of the effective local institutions, which will be discussed further in the Policy Paper on governance and community capacity. Strategic planning for Indigenous communities is effective when it combines economic development and community planning aspects (Williams 2010, Curry and Donker 2010). This includes a process that is inclusive of, and empowers, different groups and interests in the community, and incorporates accessible information and data to support this dialogue. Funding support may need to be provided to coordinate and support this community planning process including for technical expertise, capacity building, and access to data and information. This community-led economic planning provides the basis for identifying strategies to drive development, and to prioritise and coordinate investments in key enabling factors (human capital, infrastructure, and innovation).

This collective vision for development should also be linked with factors that enable the growth of Indigenous enterprises. The productivity and growth performance of rural areas tends to be influenced by two key factors: (i) proximity to cities; and, (ii) size and performance of the tradeable sector (OECD 2016). There are four main framework conditions that can improve performance of the tradeable sector:

1. Specialisation in natural resource exploitation and stewardship, which includes mining, forestry, food production, renewable energy, tourism, and ecosystem services (particularly for remote areas);

2. Rural-urban linkages that can strengthened through shared governance and policies, and better infrastructure connections;

3. Integration in Global Value Chains (GVCs). Forward and backward linkages (re-bundling) are critical to maximize value-added of natural resource industries and FDI through the creation of a network of local suppliers; and,

4. Territorially differentiated products and services through mobilisation of local assets, and leveraging consumer preferences for local or traceable products.

Each of these framework conditions has different policy implications for Indigenous communities. Natural resource exploitation is largely dependent upon the appropriate regulatory environment, and infrastructure connections. If Indigenous peoples have clarification in relation to land rights, they can have the opportunity to give consent to developments and negotiate benefit-sharing agreements. These benefits may include employment and training for local community members, and access to procurement opportunities for local businesses. Rural-urban linkages are also influenced by infrastructure connections, and shared governance arrangements that enable coordination between jurisdictions (e.g. fostering connections and complementarities with surrounding communities' off-reservation). Integration with GVCs is shaped by procurement policies and support, access to finance, and skills and competencies. Product differentiation depends, to a degree, on coordination between different actors at a local level (e.g. through clusters and shared branding). This has the potential to be a key growth area for Indigenous 
businesses linked with the authenticity, quality, sustainability, and traceability of products (food, handicrafts, music, arts and culture). These growth opportunities and constraints can also shift through technological innovations. For example, advances in digital technologies and distributed manufacturing may also generate new small business opportunities for Indigenous peoples in rural and remote areas.

\subsubsection{Mechanisms to negotiate benefit sharing agreements}

The regulatory environment, including some of the regulatory issues have been covered earlier such as clarity about land ownership and use rights, and intellectual property is also important. Land ownership and use rights can include clarity in terms of zoning for commercial land, and procedures for leasing and developing land (this will be covered further in the Policy Paper about land governance). Another important aspect of the regulatory environment is effective mechanisms for Indigenous communities to negotiate commercial ventures with entities outside of the community. These partnerships bring expertise, capital, information and procurement opportunities which reduce financial risks and barriers to entry for Indigenous communities into certain industries (e.g. food production, mining, and tourism) (Williams 2010). Specific legal instruments have been developed in Australia and Canada that enable negotiation about benefits from resource extraction for Indigenous communities (Box 1). In the case of Canada a number of shortcomings have been identified in their Impact and Benefit Agreements (IBAs), which include: lack of transparency that limits sharing of best practices and evaluation of outcomes, unequal distribution of benefits to community elites, and how some elements can be realised if they are dependent on public investment in infrastructure and services (e.g. access to education and training) (OECD 2016b). 


\section{Box 5.1. Legal instruments to enable negotiation between Indigenous communities} and mining proponents

\section{Australia - Indigenous Land Use Agreements}

Indigenous Land Use Agreements (ILUA), entered between people who hold 'native' title over a particular area and a mining developer. ILUAs can cover topics such as native title holders agreeing to a future development; how native title rights coexist with the rights of other people; access to an area; extinguishment of native title; compensation; employment and economic opportunities for native title groups; and cultural heritage. This instrument was created to give a transparent and flexible way to address potential conflict between people who hold native title and resource development. These agreements are usually processed, notified and registered in a period of less than 6 months, and are an alternative to making a native title determination through a judicial process.

One example of ILUA is the agreement signed in 2001 between the Weipa bauxite mine (Rio Tinto Alcan), the Aboriginal community, four Shire Councils, the Queensland state government and the Cape York Land Council. The Agreement led to the creation of the Western Cape Communities Trust (WCCT), which lays emphasis on local capacity building and business development. The mining firm has also committed to undertake various employment, training and infrastructure initiatives.

\section{Canada - Impact and Benefit Agreements}

In Canada the Crown has a legal duty to negotiate with Indigenous peoples on traditional lands who are affected by development. Impact and Benefit Agreements (IBAs) have evolved as a contractual instrument to negotiate benefits for Indigenous peoples related to resource developments. Prior to 2005, IBAs focused primarily on benefits relating to jobs, training and procurement opportunities. Since 2005, IBAs have increasingly emphasized economic benefits and financial issues such as royalties and direct payments. They can now contain provisions related to labour (e.g. agreed targets for Indigenous employment and training), economic development (e.g. procurement opportunities), community (e.g. social programmes and community infrastructure), environmental protection, financial (monetary compensation and monitoring arrangements), and commercial (e.g. dispute resolution). These contracts are usually confidential.

Source: OECD (2016b) Local Content Policies in Mineral-Exporting Countries, Working Party of the OECD Trade Committee

\subsubsection{Increasing access to capital and markets}

Businesses in remote rural areas can have difficulties in accessing capital and this problem is amplified for Indigenous entrepreneurs. One way to address this problem is to establish Indigenous owned financial institutions (OECD 2018). For example, Native Community Development Financial Institutions (CDFI) in the United States can include loan funds, credit unions, banks, thrifts, and depository institution holding companies that share a 
mission to promote economic development for Indigenous communities (Native Nations Institute 2016). Native CDFIs in North America provide a variety of different banking and financial services, together with programmes to build the skills, capabilities, and financial literacy of Indigenous entrepreneurs and community members. As already discussed, some of the basic preconditions for entrepreneurship can also be lacking (business planning, marketing, accounting, and appropriate premises). Some Indigenous communities in North America have established local economic development organisations that can provide these services and co-working space for start-ups (Native Nations Institute 2016). This is one way of providing a business incubator platform in traditional settlement areas. Another area may be finding ways to link angel investors (particularly those with a focus on ethical of investment) with Indigenous entrepreneurs and start-ups (KPMG 2016). In Australia, seed funding and capacity building has also been provided for Aboriginal social enterprises which found a strong demand for this type of initiative (NSW Ombudsman 2016). The private sector can also play a proactive role in increasing access to finance for Indigenous peoples, which includes educational programmes and raising awareness amongst mainstream financial institutions (NSW Ombudsman 2016).

In terms of market access there are a number of initiatives which can be considered. The first is the inclusion of Indigenous businesses and organisations in trade negotiations and climate agreements (and potentially trade missions, and international economic forums). The main issue identified in the literature is the appropriate recognition and protection Indigenous Intellectual Property, and Indigenous communities also have an economic interest in climate agreements because of the potential for carbon sequestration and payments for environmental services on traditional lands. The second is related to private and public sector procurement. In terms of private sector procurement the main area of opportunity is mining and extractive industries (metals, minerals, oil and gas), which in Latin America, Asia, Australia and New Zealand and Africa can affect traditional settlement areas. Proactive actions by the private sector can include making procurement information available to Indigenous communities, providing technical and mentoring support to Indigenous entrepreneurs, and ensuring successful tenderers have plans in place to employ and train Indigenous people (International Council on Mining and Metals 2015, NSW Ombudsman 2016). Public procurement is also an area which can increase demand for goods and services from Indigenous owned businesses. For example, in the Australian state of New South Wales public agencies can purchase goods and services of a value up to $\mathrm{A} \$ 150,000$ from an Aboriginal business if the supplier's rates are reasonable and consistent with normal market rates, and the agency obtains at least one written quotation. The Federal Government in Australia has gone one step further and set a target for Indigenous procurement in 2015. In the first 6 months of this new regime there was a rapid expansion of Indigenous businesses in the public procurement market (NSW Ombudsman 2016). 


\section{Summary}

The objective of this paper was to identify the key challenges, opportunities and policies to promoting Indigenous business growth and innovation in rural areas. The literature shows that there are a wide range of business activities undertaken by Indigenous peoples across different countries ranging from natural resource based industries that are integrated into global value chains to subsistence agriculture and livelihoods that are not. This diversity is due to the different histories, institutional contexts, access to resources, the influence of traditional livelihoods, and levels of development experienced by Indigenous peoples. Cultural values and norms do influence the nature of this economic participation, and economic development policies should be designed in a way that matches these values, and recognises the diversity of economic activity undertaken by Indigenous peoples.

Each Indigenous community will have a different starting point on its economic development journey. A key to sustained long-term Indigenous economic development in rural areas is creating the conditions for the growth of businesses that are competitive in regional, national and international markets - the growth of these businesses can break dependency relationships and support self-determination. Indigenous businesses engaged in the tradeable sector in rural areas are usually connected with a narrow range of placebased absolute advantages associated with natural resources, amenities, and traditional knowledge. Inward investment, in partnership with Indigenous communities, is important to activating these opportunities.

Businesses in rural areas face a number of challenges such as distance to markets, lower levels of skills, access to finance and specialised services, and the availability of business premises - these challenges tend to be amplified for Indigenous businesses particularly on traditional lands. Indigenous businesses on traditional lands can take diverse forms including being initiated by individual entrepreneurs, linked to collective efforts to improve community wellbeing, and joint ventures with non-Indigenous organisations. Three key factors are identified as important to creating an enabling environment for Indigenous businesses:

1. A place-based vision and priorities for Indigenous economic development that can facilitate the coordination of public and private investment in enabling factors, strengthen rural-urban linkages, participation in global value-chains, and encourage product differentiation;

2. Appropriate regulatory environment governing investment and capital accumulation related to Indigenous land assets including clarity about land tenure and use rights, and mechanisms to negotiate shared benefit agreements with investors; and,

3. Initiatives that increase access to capital and markets for Indigenous owned businesses (e.g. community development finance and procurement) to support growth and value-adding opportunities. 


\section{Bibliography}

Altman, J.C. (2004) 'Economic Development and Indigenous Australia: contestations over property, institutions and ideology', The Australian Journal of Agricultural and Resource Economics, 48:3, pp. $513-534$

Anderson, R.B. (1997) 'Corporate/Indigenous partnerships in economic development: The First Nations in Canada, World Development, Vol. 25, No. 9, pp. 1483 -1503.

Cleary, J. (2012) 'It would be good to know where our food goes: Information equals power?', in Drahos, P. and Frankel, S. Indigenous Peoples' Innovation: Intellectual Property Pathways to Development, ANU Press.

Coria, J. and Calfucura, E. (2012) 'Ecotourism and the development of indigenous communities: The good, the bad, and the ugly', Ecological Economics, 73 (2012) 47-55

Cornell, S. (2006) What Makes First Nations Enterprises Successful? Lessons from the Harvard Project, Native Nations Institute and The Harvard Project on Indian Economic Development.

Curry, J. and Donker, H. (2010) 'Economic Development in Aboriginal Communities', in Halseth, G., Schwamborn, J., Gerow, R. and Gjertsen, T. (2010) Understanding Indigenous Economic Development in Northern, Rural, and Remote Settings: Frameworks for Change

Dana, L. (2007) 'Toward a multi-disciplinary definition of indigenous entrepreneurship' in Dana, L. and Anderson, R. International Handbook of Research on Indigenous Entrepreneurship, Edward Elgar, UK.

Dana, L. and Anderson, R (2007) 'A multidisciplinary theory of entrepreneurship as a function of cultural perceptions of opportunity', in Dana, L. and Anderson, R. International Handbook of Research on Indigenous Entrepreneurship, Edward Elgar, UK.

Disney, R. (2010) Experiences of the Old Masset Village Council, in Halseth, G., Schwamborn, J., Gerow, R. and Gjertsen, T. (2010) Understanding Indigenous Economic Development in Northern, Rural, and Remote Settings: Frameworks for Change

Drahos, P. and Frankel S. (2012) Indigenous People's Innovation: Intellectual Property Pathways to Development, ANU University Press.

Henderson J. (2002), "Building the Rural Economy with High Growth Entrepreneurs", Federal Reserve Bank of Kansas City Economic Review, Vol. 3, No. 87, Federal Reserve Bank of Kansas City, pp. 4570.

International Council on Mining and Metals (2015) Good Practice Guide - Indigenous Peoples and Mining, $2^{\text {nd }}$ edition

KPMG (2016) Collaborative Ideas for Igniting the Indigenous Economy

Native Nations Institute (2016) Access to capital and credit in Native Communities, digital version. Tucson, AZ: Native Nations Institute.

New South Wales (NSW) Ombudsman (2016) Fostering Economic Development for Aboriginal People in New South Wales - A special report to Parliament under S.31 of the Ombudsman Act 1974, Government of New South Wales, Australia.

North, D. and D. Smallbone (2006), "Developing Entrepreneurship and Enterprise in Europe's Peripheral Rural Areas: some Issues Facing Policy makers", European Planning Studies, Vol. 14, No. 1, Taylor and Francis, pp. 41-60. 
Noya, A. and E. Clarence (2013), "Entrepreneurial Activities in Europe - Social Entrepreneurship", OECD Employment Policy Papers, No. 3, OECD Publishing, Paris. http://dx.doi.org/10.1787/5jxrcml2kdtd-en

OECD (2006a), "Reinventing Rural Policy”, Policy Brief, OECD Observer, October, Paris.

OECD (2009) OECD Local Entrepreneurship Reviews: Strengthening Entrepreneurship and Economic Development in East Germany: Lessons from local approaches, accessed 6 November 2017, http://www.oecd.org/site/cfecpr/42367462.pdf

OECD (2012) Promoting Growth in all Regions, OECD Publishing, Paris.

OECD (2016) OECD Regional Outlook, OECD Publishing, Paris.

OECD (2016a) OECD Territorial Reviews - Northern Sparsely Populated Areas, OECD Publishing, Paris.

OECD (2016b) Local Content Policies in Mineral-Exporting Countries, Working Party of the OECD Trade Committee.

OECD (2017) The Missing Entrepreneurs - policies for inclusive entrepreneurship, OECD Publishing, Paris.

OECD (2018) Indigenous employment and skills strategies in Canada: towards inclusive growth, OECD Publishing: Paris.

OECD (2018a) Productivity and jobs in a globalised work: how can all regions benefit? OECD Publishing: Paris.

Peredo, A.M, Anderson, R.B, Galbraith, C.S, Honig, B., Dana, L.P. (2004) 'Towards a theory of Indigenous entrepreneurship', International Journal of Small Business and Entrepreneurship, Vol: $1: 1-2$.

Peredo, A.M and Anderson, R.B (2006) 'Indigenous Entrepreneurship Research: Themes and Variations' in C. S. Galbraith \& C. H. Stiles (Eds.), 2006, Developmental Entrepreneurship: Adversity, Risk, and Isolation (pp. 253-273). Oxford, UK: Elsevier.

Ronning, L. (2007) 'Entrepreneurship among Sami Reindeer herders', in Dana, L. and Anderson, R. International Handbook of Research on Indigenous Entrepreneurship, Edward Elgar, UK.

Taylor, J. (2008) 'Indigenous peoples and indicators of well-being: Australian perspectives on United Nations Global Frameworks', Social Indicators Research, Vol 87:1, 111-126.

Westhead, P, M. Wright and D. Ucbasaran (2001), Think Global, Act Local: International Market Selection Strategies Reported by Rural and Urban Firms, Discussion Paper, Institute for Enterprise and Innovation, Nottingham University Business School.

Williams, T. 'Journey to Economic Independence: BC First Nations' Perspectives' in Halseth, G., Schwamborn, J., Gerow, R. and Gjertsen, T. (2010) Understanding Indigenous Economic Development in Northern, Rural, and Remote Settings: Frameworks for Change

Wyer, P. and D. Smallbone (1999), "Export activity in SMEs: a framework for strategic analysis", Journal of Academy of Business Administration, Vol. 4, No. 2, Academy of Business Administration, pp. 9-24.

Zacharis A., W. Bygrave and D. Shepherd (2000), Global Entrepreneurship Monitor: National Entrepreneurship Assessment, Executive Report USA, Ewing Marion Kauffman Foundation, Kansas City. 